\title{
Burning Analysis of Motor Scooters
}

\author{
CHIEN-JUNG CHEN ${ }^{1}$, MING-JU TSAI ${ }^{1}$, BO-CHIN JI ${ }^{2}$, CHAN-WEI WU ${ }^{2}$, \\ JEN-YUNG PU ${ }^{2}$, and TA-HUI LIN ${ }^{2}$ \\ ${ }^{1}$ Architecture and Building Research Institute \\ Ministry of Interior \\ Taiwan, ROC \\ ${ }^{2}$ Department of Mechanical Engineering \\ National Cheng Kung University \\ Taiwan, ROC
}

\begin{abstract}
A series of burning tests were conducted on motor scooters by using a $10 \mathrm{MW}$ large-scale fire products collector. The emissions characteristics and heat release rates of burning motor scooters were identified. From the experimental measurements, it was found that one motor scooter had a peak heat release rate of $1 \mathrm{MW}$, furthermore two scooters and three scooters had $2 \mathrm{MW}$ and $4 \mathrm{MW}$ peak heat release rate respectively. As the number of scooters increased, the duration of the fully-developed burning period became shorter. However, the ignition and fire spreading patterns affected the maximal heat release rate considerably.
\end{abstract}

KEYWORDS: motorcycle fires, heat release rates, large-scale fire products collector

\section{INTRODUCTION}

Recent statistical data on public fire cases in Taiwan showed that motorcycles have become preferred targets for arsonists. Additionally, when the number of motorcycles reached 12 million in Taiwan, their abundant presence in every corner and their flammable materials have made them increasingly important elements of fire hazards. The understanding of their burning and heat release characteristics has become urgent and thus worth a great deal of research.

Motorcycle fires have been studied sparsely in the literature. Many earlier researches on motorcycle fires were conducted without the measurement of the heat release rate due to the lack of a large-scale fire products collector. Chang [1] measured the heat release rates of individual motorcycle parts in a small-scale calorimeter, and then conducted a fire test of the whole motorcycle in an open space. The heat release rate of a 125 cc motorcycle was estimated from the flame height to be close to 1.22 MW. Lin [2] studied the fire spread pattern associated with an arcade under which several motorcycles were parked. The arcade could be one to three spans and may or may not be equipped with combustible ceiling. A correlation was made on the fire spread as a function of the amount of combustible ceiling and the number of spans. Lin [3] used a gas burner to simulate typical motorcycle fires at a $1 / 4$ reduced scale for a comparative analysis. He correlated the effects of the depth and length of an arcade on the flame height, temperature, and heat release rate.

All past researches were focused on the temperature field or the scaled-down modeling. No full-scale fire tests on motorcycles with a calorimeter have been found in the literature because it has never been a major concern for the fire test centers in Europe and North America, where most large-scale fire test devices were located. In Taiwan, a $10 \mathrm{MW}$ fire products collector running on the principles of ISO 9705 [4] has recently been developed 
by the Architecture and Building Research Institute and has been set forth for fire research for the purpose of setting up domestic fire data. By means of this fire products collector, full-scale fire tests of one, two and three motorcycles with similar construction and constituent materials were conducted. The heat release rate and fire spread data collected from the fire tests will prove essential for the fire protection agencies when dealing with motorcycle fires.

\section{EXPERIMENTAL PROCEDURE}

The 10 MW fire products collector used for determining the heat release rate of a large-scale fire is shown in Fig. 1. The fire test was conducted under the suction cone with square inlet $(4.62 \mathrm{~m} \times 4.62 \mathrm{~m})$, which possessed a maximal suction capacity of $30 \mathrm{~m}^{3} / \mathrm{s}$, provided by a suction fan (controlled by a frequency converter with the range of $1-55 \mathrm{~Hz}$ ) at the end of the pipeline. The suction cone took in the combustion gases into the circular pipeline of diameter $1.524 \mathrm{~m}$. The combustion gases then went through an instrumental section downstream of the horizontal part of the pipeline, which was equipped with measuring devices for temperatures, flow rates, and species concentrations $\left(\mathrm{O}_{2}, \mathrm{CO}, \mathrm{CO}_{2}, \mathrm{NO}_{\mathrm{X}}, \mathrm{HC}\right)$.

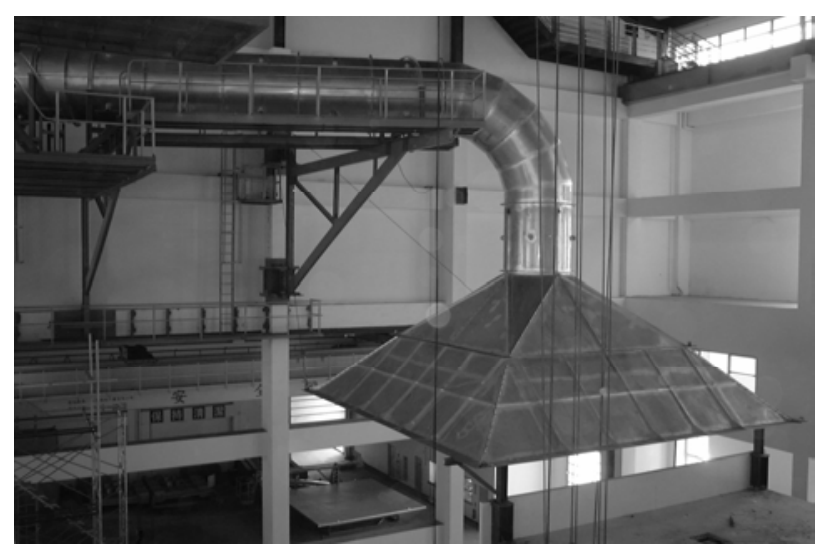

Fig. 1. Fire products suction cone and pipeline.

The motor scooters were placed on a platform at a height of $5.8 \mathrm{~m}$ above the ground so as to make the collection of the fire products gases more efficient. This means that the distance from the platform to the rim of the suction cone was $4.2 \mathrm{~m}$. The motor scooters for the fire tests were used and were similar in construction and constituent materials. For all cases tested in this study, the gasoline tanks of the scooters were emptied in order that explosions caused by the residual gasoline would not occur.

The ignition of the scooters was made by the fire of a gasoline pan with $40 \mathrm{~cm}$ in diameter under the scooters. The ignition positions selected for one scooter tests are indicated by symbols "a" and "b" as shown in Fig. 2a. We designated the case of burning one scooter with ignition at position a by $\mathrm{N}=1 \mathrm{a}$, where the pan with $300 \mathrm{cc}$ gasoline was placed squarely under the footrest. In the case of $\mathrm{N}=1 \mathrm{~b}$, burning one scooter with ignition at position b, the pan contained 200 cc gasoline and was placed only half under the footrest so that half of the fire of the gasoline pan could go directly upward. In both cases, the suction capacity of the fire products collector was $12 \mathrm{~m}^{3} / \mathrm{s}$.

For the case of $\mathrm{N}=2$, burning two scooters, a pan of 200 cc gasoline indicated by symbol "a" in Fig. 2b was placed between the two scooters separated by $20 \mathrm{~cm}$ from footrest to 
footrest. The suction capacity of $\mathrm{N}=2$ was set at $12 \mathrm{~m}^{3} / \mathrm{s}$ in the beginning and later raised to $21 \mathrm{~m}^{3} / \mathrm{s}$ to accommodate the increasing burning rate. For the case of $\mathrm{N}=3$, burning three scooters, a pan of 200 cc gasoline shown by symbol "b" in Fig. 2c was placed under the center scooter of the three scooters. The suction capacity of N=3 was set at $25 \mathrm{~m}^{3} / \mathrm{s}$ in the beginning and later increased to $27 \mathrm{~m}^{3} / \mathrm{s}$. According to the major parts of flammable material and the fire spreading pattern during the experiments, the scooter was divided into six major parts, as designated by A, B, C, D, E, and F shown in Fig. 2d, for easier reference in the description of the fire spread.

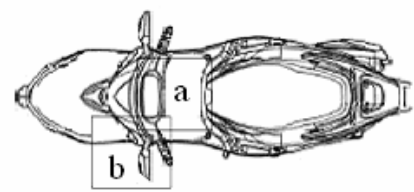

(a)

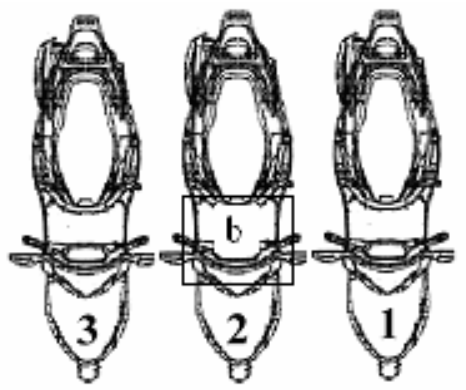

(c)

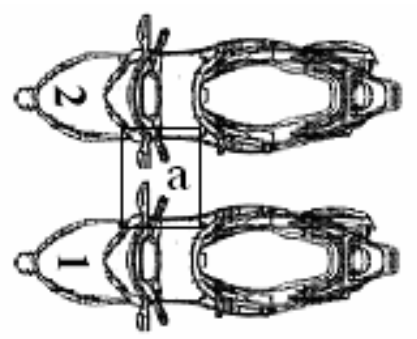

(b)

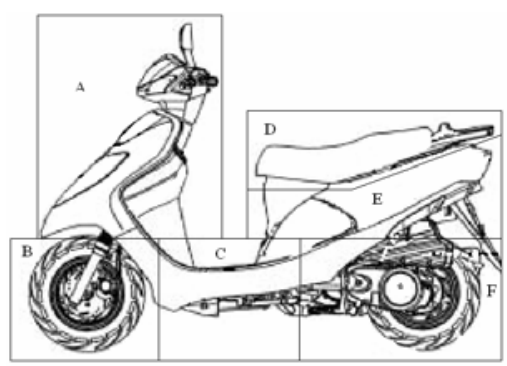

(d)

Fig. 2. Ignition positions for (a) one, (b) two, and (c) three scooters, and (d) the six major flammable parts of a motor scooter.

Following the ISO 9705 [4], the heat release rate was calculated by using either the oxygen consumption (OC) method or the gas temperature rise (GTR) method, and was correspondingly denoted by $\dot{Q}_{O}$ and $\dot{Q}_{T}$. Certainly, the oxygen consumption method gives us the total heat release rate of the fire. However, the gas temperature rise method only accounts for the convective part of the total heat release and therefore its value is much lower than the calculation by the oxygen consumption method. From our experiences in large-scale oil-pool and wood-cribs fire tests [5], the radiation heat release rate measured by a radiometer approximately equals the difference between the heat release rates obtained by the OC and the GTR method.

\section{RESULTS AND DISCUSSIONS}

\section{Burning Tests of One Motor Scooter}

The ignition and fire spreading pattern directly affected the heat release trend, therefore, our discussion started with a brief description of the burning process. Figure 3 presents a typical photograph and fire products characteristics for one scooter tests of $\mathrm{N}=1 \mathrm{a}$ and 
$\mathrm{N}=1 \mathrm{~b}$. For the case of $\mathrm{N}=1 \mathrm{a}$, the footrest was ignited at $\mathrm{t}=79 \mathrm{~s}$, and then the flame went both forwards and backwards to ignite sections A and D (referred to Fig. 2d). At $t=134 \mathrm{~s}$, the front tire started burning and the flame height was about $2.7 \mathrm{~m}$. At t=272s, sections B and $\mathrm{F}$ started burning and the whole scooter was enveloped in flames with a great amount of smoke going up. Molten plastic parts fell onto the ground to create more burning area, while the flame height remained at about $2.6 \mathrm{~m}$. After burning for about 1000 seconds, the flammable parts of the scooter were all burnt out with some small flames due to the molten plastic left on the ground.

For the case of $\mathrm{N}=1 \mathrm{~b}$, the ignition gasoline pan fire produced higher flames initially. Consequently, the handle and the front cover of the scooter could be ignited quickly. At $\mathrm{t}=60 \mathrm{~s}$, except for the front tire, the front part of the scooter was all in flames with a flame height of $2.8 \mathrm{~m}$. The fire spread to the seat cushion at $\mathrm{t}=77 \mathrm{~s}$, but the burning was still concentrated on the front part, as shown in Fig. 3a. The rear part started burning at $t=141 \mathrm{~s}$, and at this time large portion of the front part had been consumed while molten plastics dropped to the ground. The combustion strength continued to grow as the rear part kept burning and reached its peak at about $t=420 \mathrm{~s}$. The burning ended around $\mathrm{t}=1000 \mathrm{~s}$.

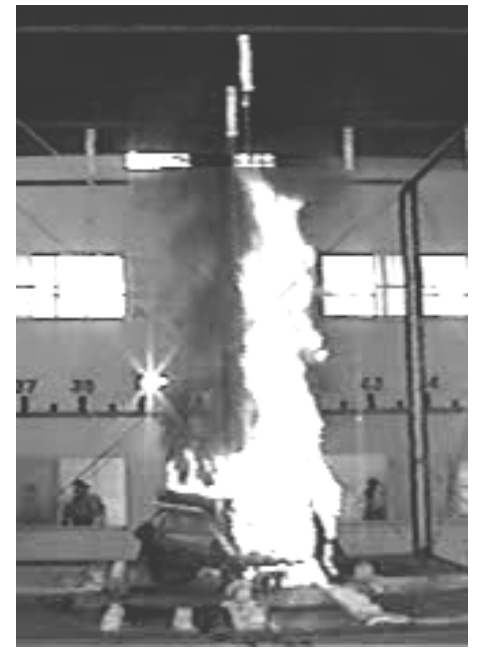

(a)

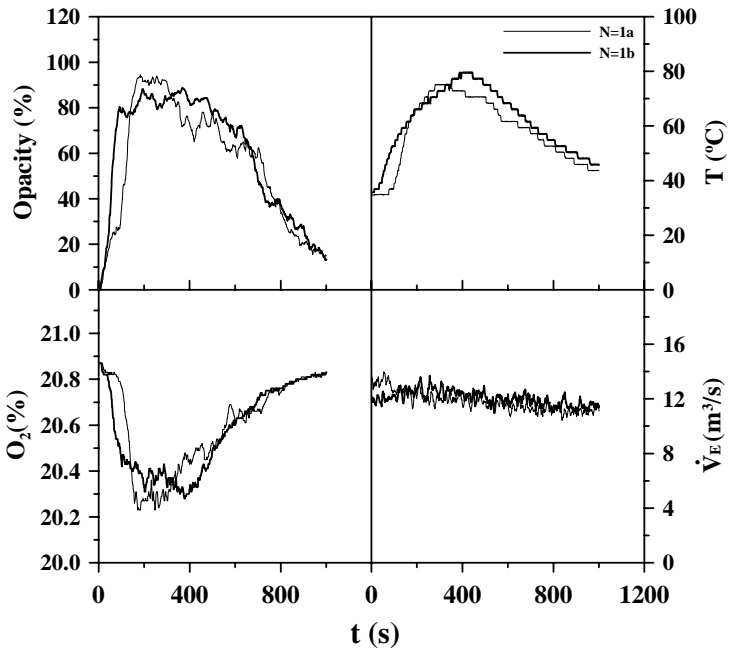

(b)

Fig. 3. (a) A typical photograph and (b) fire products characteristics for one scooter tests.

Figure 4 shows variations of flame height $(\mathrm{H})$ and heat release rates $\left(\dot{Q}_{o}\right.$ and $\dot{Q}_{T}$ ) for one scooter tests of $\mathrm{N}=1 \mathrm{a}$ and $\mathrm{N}=1 \mathrm{~b}$. The flame height was determined by means of the images obtained from the video recordings, and it represented the instantaneous maximum visible length of the fire. It is shown by Fig. 4 that the heat release rate of $\mathrm{N}=1 \mathrm{a}$ went up slower than that of $\mathrm{N}=1 \mathrm{~b}$ because of the slower ignition. The case of $\mathrm{N}=1 \mathrm{a}$ reached the fully-developed burning after 150 seconds, from which the $\dot{Q}_{o}$ stayed roughly constant; at that time the oxygen concentration dropped to $20.25 \%$ and the opacity was $91 \%$ (Fig. 3b). However, the case of $\mathrm{N}=1 \mathrm{~b}$ had its fully-developed burning from $\mathrm{t}=48$ to $470 \mathrm{~s}$, while the oxygen concentration dropped to $20.3 \%$. The peak temperatures of $\mathrm{N}=1 \mathrm{a}$ and $\mathrm{N}=1 \mathrm{~b}$ were $76^{\circ} \mathrm{C}$ and $80^{\circ} \mathrm{C}$, respectively. The peak temperature achieved was later than the beginning of the fully-developed period because of the 
heating up of the piping system and the time lag of thermocouples measurements.

From the Fig. 4, one realizes that the case of $\mathrm{N}=1 \mathrm{a}$ had its peak heat release rate at about $\dot{Q}_{o}=1.2 \mathrm{MW}$, corresponding to a flame height of $3.5 \mathrm{~m}$; while the case of $\mathrm{N}=1 \mathrm{~b}$ had a maximal $\dot{Q}_{O}$ of $0.9 \mathrm{MW}$ and a flame height of $2.5 \mathrm{~m}$. In addition, the heat release rate of $\mathrm{N}=1 \mathrm{a}$ was seen to climb very fast but decline quickly after it reached the peak heat release rate. The differences between these two cases can be attributed to their different ways of ignition. The ignition in $\mathrm{N}=1 \mathrm{a}$ was going both forwards and backwards from the bottom of the footrest; therefore, although the ignition was slower, the burning intensity was higher when both the front part and the rear part burned together. The burning also declined very quickly because the high burning intensity burned away the available flammable materials fast. On the contrary, in the case of $\mathrm{N}=1 \mathrm{~b}$, the burning spread steadily from the front part to the rear part; therefore the heat release rate was more uniform and the burning process was longer. As the flame spread from the front part to the rear part, it is interesting to note that the heat release rate slightly grew in the fully-developed period because the rear part of the scooter contained more flammable materials than the front part.

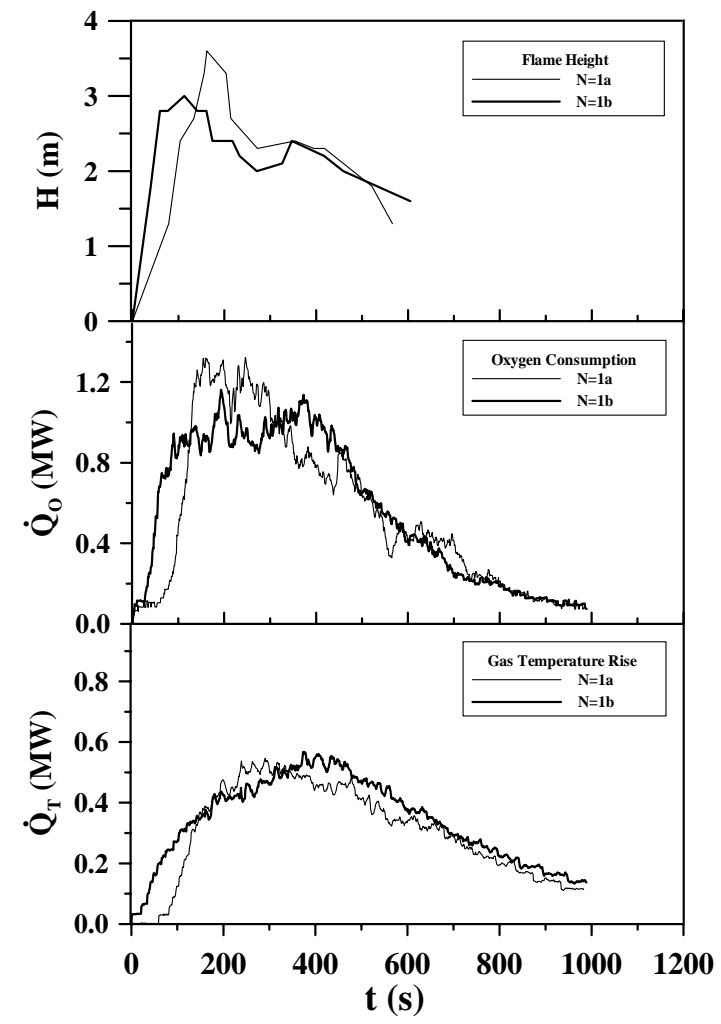

Fig. 4. Variations of flame height and heat release rates for one scooter tests.

From the fire behaviors of $\mathrm{N}=1 \mathrm{a}$ and $\mathrm{N}=1 \mathrm{~b}$, one should realize that the ignition and spread of the fire affect the peak value of the total heat release rate, the time to reach fully-developed burning, and the duration of the fully-developed burning. 
As shown in Fig. 4, the trend of $\dot{Q}_{T}$ were the same as $\dot{Q}_{o}$, but the value of $\dot{Q}_{T}$ were about $50 \%$ of $\dot{Q}_{o}$ only. If we take into account the $3 \%$ duct heat loss, we can deduce that radiation heat release is more than $45 \%$ of the total heat release in a motorcycle fire. From our previous findings [5], the radiation heat release was approximately $44 \%$ and $33 \%$ of the total heat release for large-scale oil-pool and wood-cribs fires respectively. It is therefore suggested that the motor scooter fire has strong radiation influence similar to the oil-pool fire.

\section{Burning Tests of Two and Three Motor Scooters}

In this section, we present burning tests of two scooters $(\mathrm{N}=2)$ and three scooters $(\mathrm{N}=3)$ in comparison with the case of $\mathrm{N}=1 \mathrm{~b}$. Typical fire photographs for two scooters and three scooters are shown by Fig. 5a and Fig. 5b, respectively. Figure 6 presents fire products characteristics for the cases of $\mathrm{N}=1 \mathrm{~b}, \mathrm{~N}=2$, and $\mathrm{N}=3$. Furthermore, variations of flame height $(\mathrm{H})$ and heat release rates $\left(\dot{Q}_{O}\right.$ and $\dot{Q}_{T}$ ) for the cases of $\mathrm{N}=1 \mathrm{~b}, \mathrm{~N}=2$, and $\mathrm{N}=3$ are summarized in Fig. 7.

For the case of $\mathrm{N}=2$, burning two scooters, the ignition fire from the pan of gasoline was unblocked and went high to ignite the front part of the two scooters very quickly. At $\mathrm{t}=105 \mathrm{~s}$, the burning was quite intense and the smoke produced was too much for the suction funnel to take in; therefore, we increased the suction fan converter frequency from $20 \mathrm{~Hz}$ to $35 \mathrm{~Hz}$, corresponding to the increase of suction rate from $12 \mathrm{~m}^{3} / \mathrm{s}$ to $21 \mathrm{~m}^{3} / \mathrm{s}$. After 160 seconds, sections A, B, C, and D of both scooters were in flames with molten plastics dropped to the ground. At $t=291 \mathrm{~s}$, both scooters were burning in full intensity and the flame rose to a height of $4 \mathrm{~m}$, as shown in Fig. 5a. After about 970 seconds from the ignition, the burning diminished and the heat release rate dropped too low to be measurable.

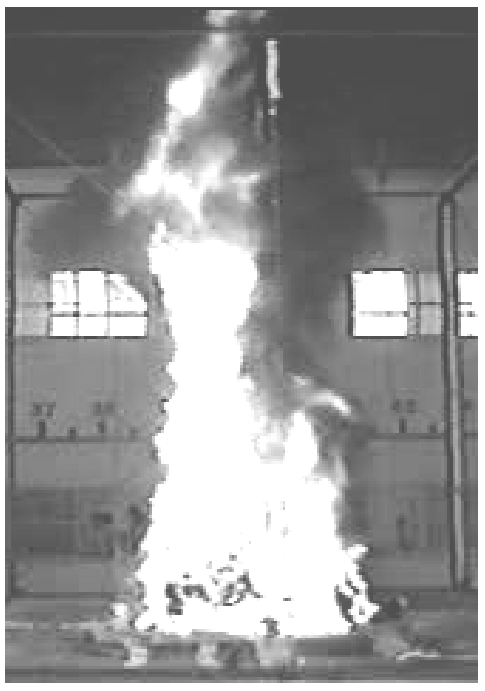

(a)

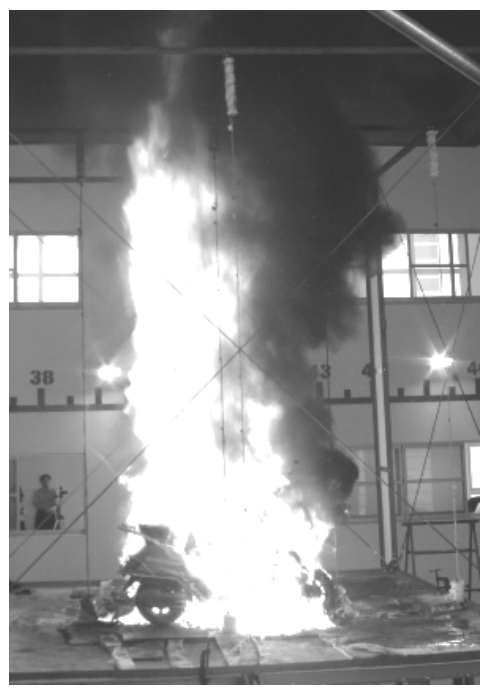

(b)

Fig. 5. Typical photographs for (a) two scooter tests and (b) three scooter tests. 
From Fig. 6 and Fig. 7, it is found that the fully-developed burning of two scooters was from $t=100$ to $380 \mathrm{~s}$; the oxygen concentration dropped to $20 \%$; and the opacity was $100 \%$. The peak temperature of the fire products gases, $100^{\circ} \mathrm{C}$, was reached at $\mathrm{t}=300 \mathrm{~s}$. From the curve of $\mathrm{N}=2$ in Fig. 7, we can see that the total heat release rate, $\dot{Q}_{0}$, at the fully-developed burning was about 2 MW. Since the ignition and fire spread of two scooters $(\mathrm{N}=2)$ were similar to those of one scooter with ignition at position $\mathrm{b}(\mathrm{N}=1 \mathrm{~b})$, $\dot{Q}_{o}$ of $\mathrm{N}=2$ was uniform without too high a peak value. For the case of $\mathrm{N}=2$, the trend of $\dot{Q}_{T}$ was similar to $\dot{Q}_{O}$ with its peak value at $1 \mathrm{MW}$, again about $50 \%$ of $\dot{Q}_{O}$.

Considering the case of $\mathrm{N}=3$, the burning of three scooters grew noticeable when sections $\mathrm{A}$ and $\mathrm{C}$ of the center scooter were ignited at $\mathrm{t}=48 \mathrm{~s}$. Then at $\mathrm{t}=72 \mathrm{~s}$, section $\mathrm{A}$ of the two side scooters were subsequently ignited. At $\mathrm{t}=163 \mathrm{~s}$, except for sections $\mathrm{E}$ and $\mathrm{F}$ of the two side scooters, all the other sections were in flames; large quantity of smoke was produced and the flame height was about $3.6 \mathrm{~m}$. After about 257 seconds, section $\mathrm{E}$ of the two side scooters started burning with a flame height of $4 \mathrm{~m}$. At this time, frequent burn-out phenomenon above the flame could be noticed, as shown in Fig. 5b. At $t=300 \mathrm{~s}$, all the three motor scooters were burning in high intensity. The exact flame height could not be measured because the flame had lifted into the suction cone, but it must be higher than $4.2 \mathrm{~m}$. The suction capacity was raised to $27 \mathrm{~m}^{3} / \mathrm{s}$ at $\mathrm{t}=428 \mathrm{~s}$ to accommodate the growing amount of smoke produced. The burning stopped at about 1100 seconds from ignition.

Figures 6 and 7 show that the fully-developed burning of three scooters was from $\mathrm{t}=130$ to $370 \mathrm{~s}$; the oxygen concentration dropped to $19.6 \%$; and the opacity was $100 \%$. The peak temperature of the fire products gases, $130^{\circ} \mathrm{C}$, was reached at $\mathrm{t}=300 \mathrm{~s}$. From the curve of $\mathrm{N}=3$ in Fig. 7, we notice that the total heat release rate, $\dot{Q}_{o}$, at the

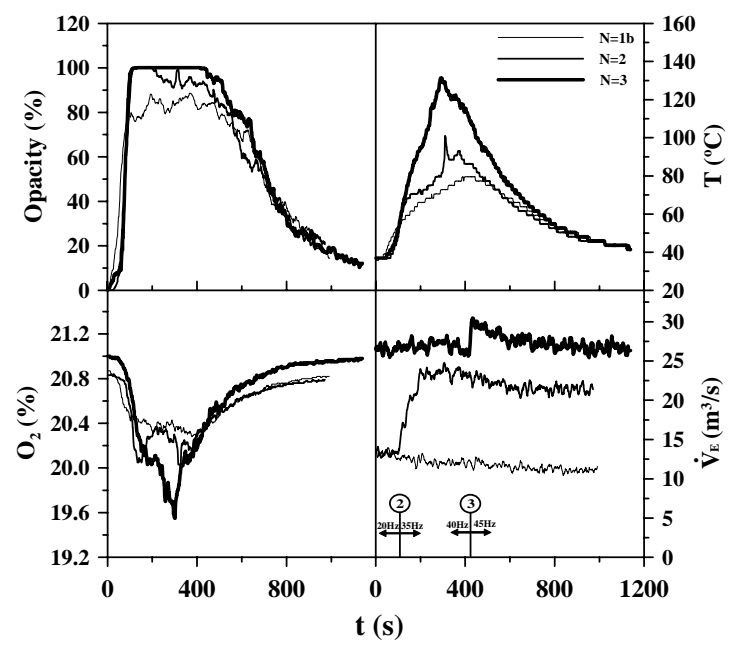

Fig. 6. Fire products characteristics for the cases of $\mathrm{N}=1 \mathrm{~b}, \mathrm{~N}=2$, and $\mathrm{N}=3$. 


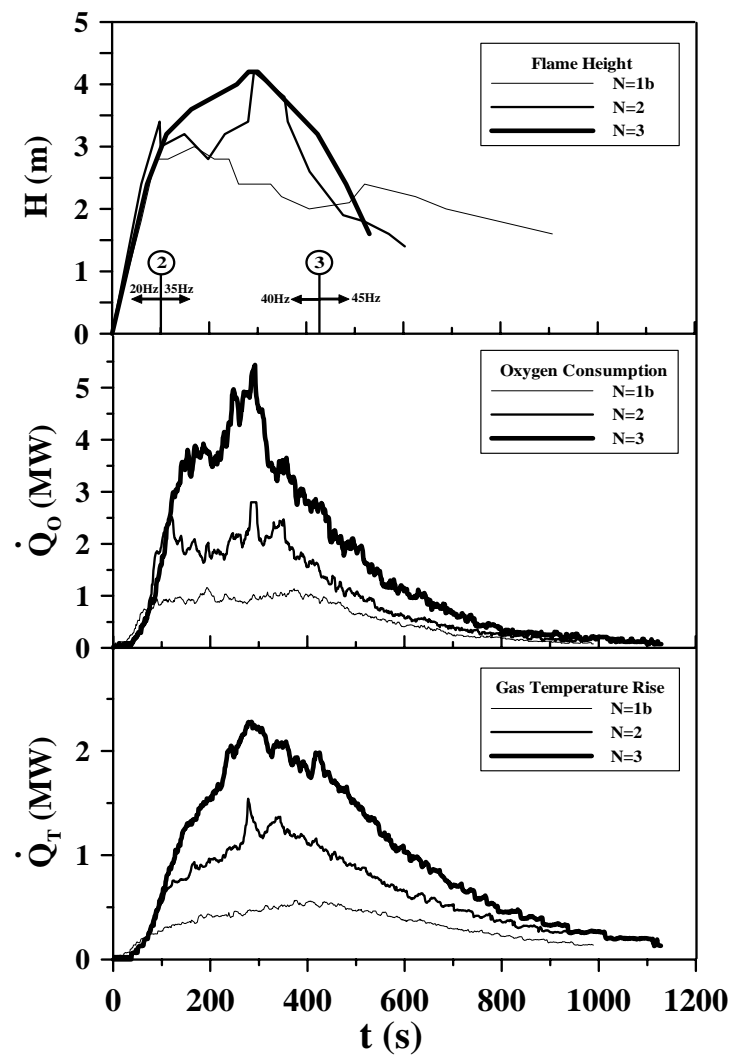

Fig. 7. Variations of flame height and heat release rates for the cases of $\mathrm{N}=1 \mathrm{~b}, \mathrm{~N}=2, \mathrm{~N}=3$.

fully-developed burning was on the average about $4 \mathrm{MW} . \dot{Q}_{o}$ had two peak values because in the beginning the burning concentrated in the front parts, but at $=250 \mathrm{~s}$, the burning spread to the rear parts where more flammable materials were available. The trend of $\dot{Q}_{T}$ was similar to $\dot{Q}_{O}$ with an average of about $1.8 \mathrm{MW}$ during the fully-developed burning.

Variations of the heat release rates for the burning tests on one, two, and three scooters are finally compared in Fig. 7. The case of $\mathrm{N}=1 \mathrm{~b}$ was selected instead of $\mathrm{N}=1 \mathrm{a}$ because its fire spread was more similar to the cases of $\mathrm{N}=2$ and $\mathrm{N}=3$ than $\mathrm{N}=1$ a was. In Fig. 7, it is seen that the maximal heat release rates for one, two, and three scooters were approximately $1 \mathrm{MW}, 2 \mathrm{MW}$, and $4 \mathrm{MW}$, respectively. The heat release rate does not grow linearly with the number of motor scooters. The times for one, two, and three scooters reaching fully-developed burning were 80, 100, and 130 seconds, respectively. The durations of fully-developed burning for one, two, and three scooters were approximately 400, 280, and 240 seconds. In other words, the duration of fully-developed periods became shorter as the number of scooters increased. It is worth noting that the burn-out time, about 1000 seconds, does not vary with the number of the scooters.

\section{Estimation of the Total Heat Release from the Constituents of the Scooter}

Huang [6] had surveyed the usage of plastic materials on domestic motor scooters in 
Taiwan. About 12 kilograms of plastics are used on one motor scooter and the percentage breakdown is shown in Table 1. Besides the flammable plastic parts, Table 1 also includes other flammable materials, such as rubber and engine oil. Their heating values [7] and corresponding heat release amounts were calculated and summed up to find the total combustion energy release from one motor scooter, which is about 528.6 MJ.

We integrated the curves of the heat release rate $\left(\dot{Q}_{o}\right)$ in Fig. 7 to obtain the total heat release, and then subtracted the energy of the ignition gasoline from it, we finally obtained the total heat releases of one, two, and three scooters during the fire period, as shown in Table 2. The maximal difference between the measured and the estimated value for the fire tests is seen to be no greater than $9 \%$. The difference occurred herein may be partly caused by the difference of constituent materials reported by the survey [6] and burnt in this study. The above finding can be further justified by using brand-new scooters for fire tests and material analysis simultaneously in the future.

Table 1. Flammable materials of a motor scooter.

\begin{tabular}{|c|c|c|c|c|}
\hline \multicolumn{2}{|c|}{ Flammable materials of a motor scooter } & $\begin{array}{l}\text { Weight } \\
\text { (kg) }\end{array}$ & $\begin{array}{c}\text { Heating value [7] } \\
\text { (MJ/kg) }\end{array}$ & $\begin{array}{c}\text { Heat } \\
\text { release }\end{array}$ \\
\hline \multirow{5}{*}{$\begin{array}{c}\text { Plastic } \\
\text { Material } \\
{[6]} \\
(12 \mathrm{~kg})\end{array}$} & PP and composites of PP (63\%) & 7.56 & 43.23 & 326.8 \\
\hline & ABS (16\%) & 1.92 & 33.75 & 64.8 \\
\hline & PU (8\%) & 0.96 & 23 & 22.08 \\
\hline & PVC (4\%) & 0.48 & 16.9 & 8.11 \\
\hline & Others (PMMA, PC, PA, 9\%) & 1.08 & 27 & 29.16 \\
\hline \multicolumn{2}{|c|}{ Engine Oil } & 0.6 & 42.5 & 25.5 \\
\hline \multirow{2}{*}{\multicolumn{2}{|c|}{ Tire }} & 1.6 & 32.6 & 52.16 \\
\hline & Total & 14.2 & - & 528.61 \\
\hline
\end{tabular}

Table 2. Measured total heat release.

\begin{tabular}{|c|c|c|c|c|}
\hline $\begin{array}{c}\text { Number of } \\
\text { motor scooters }\end{array}$ & $\begin{array}{c}\text { Total heat } \\
\text { release } \\
\text { (MJ) }\end{array}$ & $\begin{array}{c}\text { Heat release of } \\
\text { gasoline }^{\mathbf{a}} \\
\text { (MJ) }\end{array}$ & $\begin{array}{c}\text { Net heat } \\
\text { release } \\
\text { (MJ) }\end{array}$ & $\begin{array}{c}\text { Difference }^{\mathbf{b}} \\
\mathbf{( \% )}\end{array}$ \\
\hline Estimated value & 528.6 & - & 528.6 & - \\
\hline 1a & 545 & 10.3 & 534.7 & $1.2 \%$ \\
\hline $1 \mathrm{~b}$ & 561.5 & 6.9 & 554.6 & $5 \%$ \\
\hline 2 & 1009.6 & 6.9 & 1002.7 & $5.2 \%$ \\
\hline 3 & 1735.9 & 6.9 & 1729 & $9 \%$ \\
\hline
\end{tabular}

${ }^{\mathrm{a}}$ The amount of gasoline in ignition pan for $\mathrm{N}=1 \mathrm{a}$ is 300cc, others are 200cc.

${ }^{\mathrm{b}}$ Percentage of difference between measured and estimated heat release.

\section{CONCLUSIONS}

The burning characteristics of one, two, and three motor scooters investigated by the 10MW large-scale fire products collector can be summarized as follows:

(1) The position of ignition affects the fire spreading pattern, the duration of fully-developed burning, and the peak heat release rate. 
(2) The maximal heat release rate does not grow linearly with the number of the motor scooters. Results show that one scooter has a peak heat release rate of $1 \mathrm{MW}$; furthermore two scooters and three scooters have $2 \mathrm{MW}$ and $4 \mathrm{MW}$ peak heat release rate respectively.

(3) The duration of full-developed burning becomes shorter as the number of scooters increases.

(4) The total heat release of burning a scooter is approximately equal to the addition of the combustion energies of all the available flammable materials, including the plastic parts, the rubber parts, and the engine oil.

\section{REFERENCES}

[1] Chang, H.F., "The Burning Behavior of the Motorcycle," Master Thesis, National Taiwan University of Science and Technology, Taiwan, ROC, 1997.

[2] Lin, W.Z., "Spread Behavior of Motorcycles in the Building Arcade," Master Thesis, National Taiwan University of Science and Technology, Taiwan, ROC, 1998.

[3] Lin, Y.C., "Study on Applying Combustion Device to Simulate Motorcycle Burning - the Influence of the Wall of Arcade on the Flame Behavior," Master Thesis, National Taiwan University of Science and Technology, Taiwan, ROC, 2001.

[4] ISO 9705, "Fire Tests-Reaction to Full-Scale Room Test for Surface Products,” International Organization for Standardization, Geneva, Switzerland, 1993.

[5] Lin, T.H., "Analysis on Full-Scale Fire Characteristics of Residential Units," Architecture and Building Research Institute, Ministry of Interior, Report 093301070000G1004, Taiwan, ROC, 2004.

[6] Huang, S.Z., "Plastic Materials for Automobile and Motorcycle," Chemical Monthly, 9, pp. 11-24, (1995).

[7] DiNenno, P.J., (ed.), “Appendix C,” The SFPF Handbook of Fire Protection Engineering $\left(2^{\text {nd }} e d\right)$, National Fire Protection Association, Quincy, MA 02269, 1995, p. A-37. 